\title{
Article
}

\section{The Use of Moldavian Dragonhead Bagasse in Shaping the Thermophysical and Physicochemical Properties of Ice Cream}

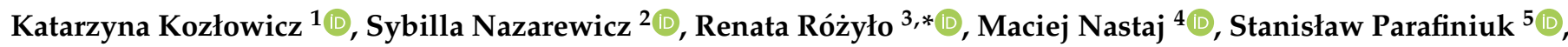 \\ Marek Szmigielski ${ }^{1}$, Agata Bieńczak ${ }^{6}$ and Natalia Kozłowicz ${ }^{7}$
}

1 Department of Biological Bases of Food and Feed Technology, University of Life Sciences in Lublin, Głęboka 28, 20-950 Lublin, Poland; katarzyna.kozlowicz@up.lublin.pl (K.K.); marek.szmigielski@up.lublin.pl (M.S.)

2 Department of Agricultural, Forestry and Transport Machines, University of Life Sciences in Lublin, Głęboka 28, 20-950 Lublin, Poland; sybilla.nazarewicz@up.lublin.pl

3 Department of Food Engineering and Machines, University of Life Sciences in Lublin, Głęboka 28, 20-950 Lublin, Poland

4 Department of Dairy Technology and Functional Food, University of Life Sciences in Lublin, Skromna 8, 20-704 Lublin, Poland; maciej.nastaj@up.lublin.pl

5 Department of Machine Operation and Production Process Management, University of Life Sciences in Lublin, Głęboka 28, 20-950 Lublin, Poland; stanislaw.parafiniuk@up.lublin.pl

6 Łukasiewicz Research Network, Industrial Institute of Agricultural Machines, Starołęcka 31, 60-963 Poznań, Poland; agata.bienczak@pimr.lukasiewicz.gov.pl

7 Faculty of Medicine, Dental Medicine, Medical University of Lodz, Pomorska 251, 92-212 Lodz, Poland; natalia.kozlowicz@stud.umed.lodz.pl

* Correspondence: renata.rozylo@up.lublin.pl

check for

updates

Citation: Kozłowicz, K.; Nazarewicz, S.; Różyło, R.; Nastaj, M.; Parafiniuk, S.; Szmigielski, M.; Bieńczak, A.; Kozłowicz, N. The Use of Moldavian Dragonhead Bagasse in Shaping the Thermophysical and Physicochemical Properties of Ice Cream. Appl. Sci. 2021, 11, 8598. https://doi.org/ 10.3390/app11188598

Academic Editor: Andrea Salvo

Received: 29 August 2021

Accepted: 13 September 2021

Published: 16 September 2021

Publisher's Note: MDPI stays neutral with regard to jurisdictional claims in published maps and institutional affiliations.

Copyright: (c) 2021 by the authors. Licensee MDPI, Basel, Switzerland. This article is an open access article distributed under the terms and conditions of the Creative Commons Attribution (CC BY) license (https:// creativecommons.org/licenses/by/ $4.0 /)$.
Featured Application: The research presents the development of innovative ice cream based on rice milk with the addition of Moldavian dragonhead bagasse. Such a product can be put into industrial production.

Abstract: The aim of the study was to analyze the influence of bagasse from Moldavian dragonhead (D. moldavica L.) seeds as a source of valuable nutrients on the physicochemical properties of rice milk ice cream. The basic composition of the ice cream was modified with a varied proportion of Moldavian dragonhead bagasse (MDB) $(1.0 \%, 1.5 \%, 2.0 \%, 2.5 \%$, and $3.0 \%)$. The analysis of fatty acids showed a high proportion of linolenic acid $(n-3)$ in the tested ice cream, especially with $3.0 \%$ share of bagasse. The addition of MDB increased dry matter, fat, and protein contents in the ice cream. The increasing share of this additive affected the physical properties of ice cream, increasing hardness, adhesiveness and viscosity, and reducing their melting rate. The study showed a negligible effect of the increasing share of MDB on the thermophysical properties of ice cream. Due to the high nutritional value of the bagasse (with the appropriate refinement of the recipe), it is possible to obtain rice milk ice cream with potential health-promoting properties.

Keywords: ice cream; physicochemical properties; Moldavian dragonhead; bagasse; sustainable development

\section{Introduction}

Ice cream is a valuable accompaniment to the diet for all age groups, especially for children. The quality and variety of ice cream manufacturing have gained importance in the dairy industry. Ice cream is a frozen complex colloidal system that is composed of partially coalesced fat droplets, air cells, ice crystals, and continuous aqueous phase, wherein the polysaccharides, proteins, lactose, and minerals are dispersed. Other ingredients can be added to ice cream to confer aroma, colour, and flavour, and enhance its nutritional value and technological properties. A typical composition of ice cream consists of about $30 \%$ ice, $5 \%$ fat, $15 \%$ matrix, and $50 \%$ air by volume [1]. 
Moldavian balm (syn. Moldavian dragonhead) (D. moldavica L.) is a perennial herb belonging to the Lamiaceae (Labiatae) family. D. moldavica L. is an annual species with local (native to central Asia) and more often with global importance. D. moldavica L., due to its pleasant lemon scent and medical effects, has acquired increasing impact as a functional food [2-6].

Dragonhead seeds are rich in fatty oil [7,8], which content ranges from 18 to $29 \%$. This oil is rich in unsaturated fatty acids (about 90\%), principally the linolenic and linoleic acids (about 60 and 20\%, respectively) which belong to essential fatty acids [9]. The average protein content of dragonhead seeds is around 21\% [10]. The presence of terpenoids, flavonoids, alkaloids, lignans, phenols, coumarins, and cyanogenic glucosides has been also shown in dragonhead [11]. Different flavonoids (31) compounds were isolated from D. moldavica L., including flavonoids, flavonols, and flavonoids glycosides [11-13]. Among phenylpropanoids compounds in D. moldavica L. were found phenyl propionic acid, lignans, and coumarins [12] rosmarinic acid, and apigenin [14]. Another study [15] identified such phenolic compounds as hydroxybenzoate, hydroxycinnamates, and flavonoids. The principal constituents of essential oil of D. moldavica L., according to El-Baky and El-Baroty, [16] were geranyl acetate, geranial, geraniol, nerol, neryl acetate, neral, and linalool. In another study [17] oxygenated monoterpenes (96.3\%) were found to be the principal group of compounds, of which neral, geranial, geranyl acetate and geraniol were the major constituents of the essential oil. According to results obtained by Fattahi et al. [18] oxygenated monoterpenes $(55.4 \%)$ were the main constituents of the extracts of $D$. moldavica L.

Some authors suggest that the use of D. moldavica L. essential oil could provide a powerful tool in control of pathogenic microorganisms in the food and pharmaceutical industry. The antimicrobial potential of the essential oil of Egyptian Moldavian balm against six bacterial (Bacillus subtilis, Bacillus cereus, Staphyloccocus aureus, Microccous luteus, Klebsiella pneumoniae, Serratia marcenscens) and four fungal strains (Aspergillus niger, Penicillium notatum, Mucora heimalis, Fusarium oxysporum) was investigated by El-Baky and El-Baroty [16].

Jiang et al. [13] studied the antioxidative activity of total flavonoids extracted from D. moldavica L. The total flavonoids showed remarkable scavenging effects against 1,1diphenyl-2-picrylhydrazyl, hydroxyl, and superoxide anion radicals in vitro.

Moldavian dragonhead (D. moldavica L.) is used in traditional medicine as a stimulant and antiseptic [19]. Extracts and oil from this plant are used widely in the food, pharmaceutical, flavouring, and cosmetic industries [20]. So far, the addition of D. moldavica L. leaves has been tested in bread [21], or corn snacks [2]. Snacks were also enriched with D. moldavica L. seeds [3,22]. These seeds were used in the 3,12, and 22\% snacks recipes.

Moldavian dragonhead bagasse (MDB) (Figure 1b) is waste product from the process of pressing oil from the seeds (Figure 1a) of D. moldavica L.

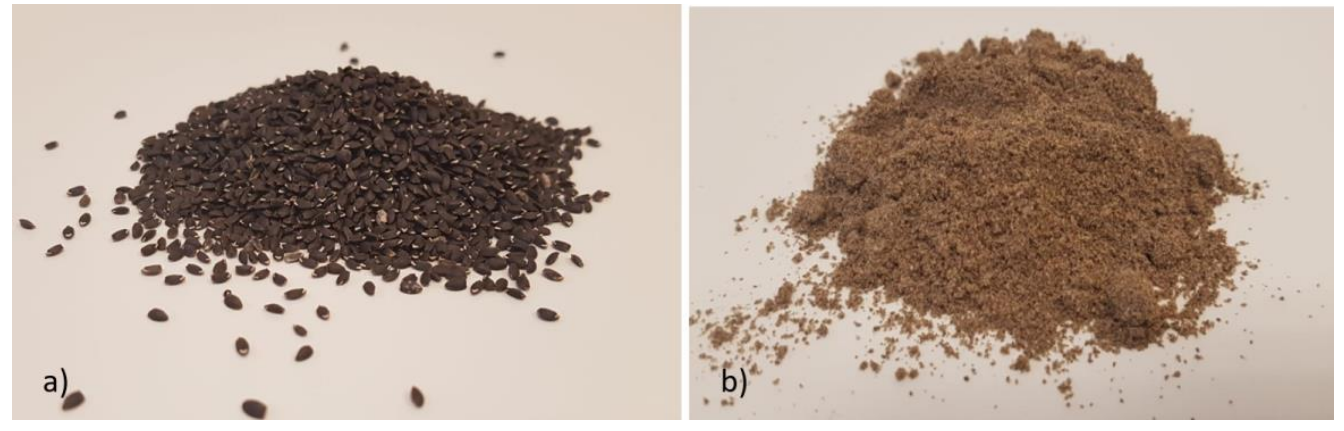

Figure 1. The appearance of seeds (a) and bagasse from D. moldavica L. (b).

The use of bagasse from these seeds has not yet been extensively tested in food production. Recently, MDB were just an addition to the production of pasta [23]. The addition of MDB to extruded products was also noted by Oniszczuk et al. [24]. 
The pasta was supplemented with MDB added to the recipe up to $25 \%$. It was found that this waste could be used in an amount of $10 \%$ for pasta; consequently, an acceptable product with high nutritional value was obtained. There was an increase in the nutritional value of protein by $5.8 \%, 145 \%$ of dietary fiber, and $50 \%$ of minerals. Moreover, MDB has a good fatty acid composition with a high proportion of linolenic acid (62.21\%) and linoleic acid $(20.39 \%)$ [23].

D. moldavica L. bagasse after the cold oil pressing were added as supplementation to corn snacks in the amount of $5-30 \%$. In these studies, the increasing amount of MDB had a significant effect on the physical properties of the extrudates. A decrease in the bulk density was noticed, but also an increase in the apparent density and the cutting force. Moreover, water absorption decreased and water solubility increased [24].

Sustainable development of waste management allows the use of bagasse, especially from seeds, as a source of valuable nutrients (fiber, protein, fat, minerals, vitamins and dyes) to enrich food products, especially ice cream. In the present study, for the first time, we proposed a waste additive from the pressing of dragonhead seed for the production of ice cream. The scope of the work included the determination of thermal and physicochemical properties of ice cream with this additive.

\section{Materials and Methods}

\subsection{Materials}

Five variants of ice cream mixes (1500 g each) were prepared with the following ingredients: homogenized (UHT) natural rice drink (Natumi, Troisdorf, Germany), hemp protein (Intenson, Poland), low sugar maltodextrin (Agnex, Shanghai, China), phacelia honey with blue phacelia (Phacelia tanacetifolia Benth.) (B. Biebrzański apiary, Poland), Moldavian dragonhead bagasse (MDB), inulin (Agnex, Bialystok, Poland), emulsifier E 471 (Fooding, Shanghai, China), and sodium carboxymethyl cellulose E466 CMC (Agnex, Bialysktok, Poland) as stabilizer.

\subsection{Production and Analysis of Bagasse}

The bagasse was obtained by pressing oil from the seeds of Moldavian dragonhead (D. moldavica L.), which came from the farm's own cultivation in Czesławice, Poland. The crops were harvested in 2017. The seeds were pressed using a screw press with a variable nozzle having a diameter of $8 \mathrm{~mm}$ together with a set of Farmet DUO sieves of continuous operation. Before starting the press, it was heated to a temperature of $50{ }^{\circ} \mathrm{C}$. After the temperature stabilized, the pressing process was started. Stabilization was achieved after pressing the oil from the mass of about $1 \mathrm{~kg}$ of seeds and the temperature at that time was about $60{ }^{\circ} \mathrm{C}$. The pressing temperature was measured with an AD 20TH digital thermometer from Amarell-ama-digit. The bagasse was stored in dark containers at $5{ }^{\circ} \mathrm{C}$ for 6 days and then it was analysed for the content of saturated and unsaturated fatty acids using gas chromatography (Bruker 436GC chromatograph with FID detector) in accordance with the relevant standards [25]. The fatty acid methyl esters were separated on a BPX 70 capillary column $(60 \mathrm{~m}, 0.25 \mathrm{~mm}, 25 \mathrm{~m})$ with nitrogen as the carrier gas. The protein and fat content in the bagasse was also determined [26].

\subsection{Ice Cream Preparation and Freezing Process}

Basic ice cream recipes were added of 5 different percentages of MDB (1.0; 1.5; 2.0; $2.5 ; 3.0 \%$ ) which determined inulin diminution (respectively 8.0, 7.5, 7.0, 6.5, 6.0\%). All percentages are shown in Table 1. (The ice cream was prepared in the traditional way. Properly weighed ingredients were mixed according to the recipe. The resulting ice cream mixture was pasteurized at $69.0^{\circ} \mathrm{C}$ for $20 \mathrm{~min}$. Honey was added to the cooled mixture $\left(20^{\circ} \mathrm{C}\right)$ and, after thorough mixing, it was subjected to the maturation process at $4{ }^{\circ} \mathrm{C}$ for $24 \mathrm{~h}$. The mixture prepared in this way was aerated with the use of a planetary mixer (Gerlingen, Bosch, Poland) for $20 \mathrm{~min}$. 
Table 1. Ice cream formulation.

\begin{tabular}{cccccc}
\hline \multirow{2}{*}{ Ingredients } & \multicolumn{5}{c}{ Composition (g/100 g, w/w) } \\
\cline { 2 - 6 } & LW1.0 & LW1.5 & LW2.0 & LW2.5 & LW3.0 \\
\hline Rice drink & 63.0 & 63.0 & 63.0 & 63.0 & 63.0 \\
Hemp & 7.5 & 7.5 & 7.5 & 7.5 & 7.5 \\
protein & & 10.0 & 10.0 & 10.0 & 10.0 \\
Maltodextrin & 10.0 & 10.0 & 10.0 & 10.0 & 10.0 \\
Honey & 10.0 & 1.5 & 2.0 & 2.5 & 3.0 \\
MDB & 1.0 & 7.5 & 7.0 & 6.5 & 6.0 \\
Inulin & 8.0 & 0.3 & 0.3 & 0.3 & 0.3 \\
Emulsifier & 0.3 & 0.2 & 0.2 & 0.2 & 0.2 \\
Stabilizer & 0.2 & & &
\end{tabular}

The freezing process was carried out in an ice cream maker (Ariete Galatera Compact, Varese, Italy) until the ice cream temperature was $-6{ }^{\circ} \mathrm{C}$. Temperature was recorded every 1 min with a mini temperature recorder (LB-515 pellets, Germany). Based on the recorded changes in temperature over time, the freezing curves were plotted with the use of Microsoft Office Excel 2007. The cryoscopic temperature of the tested ice cream was determined according to Christodulo-Rjutov using a graphic method, consisting in drawing two tangents to the freezing curve and determining their intersection point [27]. The obtained ice cream was packed in plastic containers, tempered at $-30^{\circ} \mathrm{C}$ (Whirlpool air freezer) for $24 \mathrm{~h}$, and stored for 3 days. The physicochemical properties of the ice cream were tested on freeze-dried samples The sample was lyophilized for $72 \mathrm{~h}$ at a pressure of $20 \mathrm{~Pa}$ and an ice condensation temperature of $-64{ }^{\circ} \mathrm{C}$ (ALPHA 2-4LD Plus freeze-dryer, Christ, Germany).

\subsection{Chemical Analysis of Ice Cream}

Dry matter, fat, protein, and ash contents were determined according to the AOAC standards [26]. The $\mathrm{pH}$ of the ice cream was measured with a $\mathrm{pH}$ meter (ELMETRON CP401) equipped with an ERH-11 glass electrode at a temperature of $25^{\circ} \mathrm{C}$. All measurements were performed in triplicate.

\subsection{Physical Properties of Ice Cream}

The determination of melting resistance consisted in measuring the time of appearance of the first drop and the total time of melting of a given volume of ice cream. Frozen samples $(30 \mathrm{~g})$ in the shape of a cone with dimensions: height $35 \mathrm{~mm}$, upper diameter $35 \mathrm{~mm}$, bottom diameter $25 \mathrm{~mm}$, were placed on a mesh located on the funnel and beaker (at room temperature $20^{\circ} \mathrm{C}$ ) and allowed to melt. The total melting time of the samples (in minutes) was measured from the time the first drop appeared [28].

The viscosity of the tested ice cream was measured with a Kinexus Lab + rheometer (Malvern Panalytical Ltd., Malvern, UK) in a coupled cylinder system (18 mm cylinder, $1 \mathrm{~mm}$ gap between cylinders) using a CZ5 SW 1423 SS adapter. The tests were carried out in the range of shear rate $0-250[1 / \mathrm{s}]$ at room temperature.

Hardness and adhesiveness (stickiness), was carried out in accordance with the methodology of Tiwari, Sharma, Kumar, and Kaur [29], adapted to the test requirements recommended by Brookfield Engineering Laboratories. A penetration test was performed in an LFRA texture analyzer equipped with a back extrusion chamber (Brookfield Engineering Laboratories, Inc., Middleboro, Massachusetts). The chamber was filled with a mass of ice cream at a temperature of $-6.0{ }^{\circ} \mathrm{C}$. Ice cream hardness was determined based on the maximum force $[\mathrm{N}]$ required to push the probe down to $60 \%$ of the sample height. Stickiness of the ice cream was determined by measuring a negative force while the probe was withdrawn. The following parameters were adopted for the analysis: probe diameter $-12 \mathrm{~mm}$, chamber diameter $-30 \mathrm{~mm}$, probe speed during penetration $-0.1 \mathrm{~mm} / \mathrm{s}$, and pressure force $-0.2 \mathrm{~N}$. All measurements were performed in triplicate. 


\subsection{Determination of Thermophysical Properties}

Frozen ice cream samples were analyzed for thermophysical properties such as thermal conductivity, heat capacity, and thermal diffusivity using the KD2 Prometer (Decagon Devices, Pullman, DC, USA) equipped with the SH-1 probe. The tests were performed in 5 replications at $-22{ }^{\circ} \mathrm{C}[30]$.

\subsection{Statistical Analysis}

The results were statistically analyzed using StatSoft Polska STATISTICA 13.1. The significance of the differences between the mean values of the determined parameters was verified with the Tukey test. The calculations were made at the significance level of $p<0.05$.

\section{Results and Discussion}

Chemical Analysis of Moldavian Dragonhead Bagasse

Moldavian dragonhead bagasse (MDB) is obtained by pressing oil from seeds contained $5.43 \%$ of fat (Table 2). MDB is characterized by unique content of fatty acids. Over $90 \%$ of the fatty acids present in these MDB are unsaturated, of with over $80 \%$ are polyunsaturated fatty acids [7]. Linolenic acid ALA 18:3 (62.21\%), belonging to the omega-3 group, had the highest share in the fat fraction. Linoleic acid LA (n-6) 18:2 in the tested MDB constituted more than $20 \%$ of fatty acids, and the content of oleic acid (n-9) 18:1 was approximately 10\%. Similar results were obtained by Abdel-Raheem [31], Matwijczuk [7], and Stuchlik and Žak [32]. Comparing the obtained results, e.g., with high-linolenic oils, such as linseed oil and chia, the content of linolenic acid in MDB was higher than in linseed $(50 \%)$ and chia (62\%) oils. The $n-3$ to $n-6$ ratio (3.5) was higher than that of flax (3.3) and chia (3.2) oils [7]. The human body cannot synthesize linolenic acid, and therefore, it is known, along with linoleic acid, as an essential fatty acid. Due to the high content of this fatty acid and high ratio of $n-3 / n-6$, Moldavian dragonhead seed, the extracted oil, and bagasse can be used as a food supplement, where enrichment with omega- 3 fatty acids is needed. MDB contained 23.97\% protein. According to Hanczkowski et al. [33] the seeds of the blue variety of D. moldavica L. contain approx. $21.03 \%$ protein, $24.02 \%$ fat, $11.23 \%$ fiber, and $4.91 \%$ ash. Protein is characterized by a favourable amino acid composition and high nutritional value. It contains a lot of sulphur amino acids (methionine and cystine) [33].

Table 2. Chemical composition of MDB.

\begin{tabular}{cc}
\hline Fatty Acid & Content [\%] \\
\hline Protein & $23.97 \pm 0.221$ \\
Fat & $5.43 \pm 0.120$ \\
Palmitic acid 16:0 & $5.83 \pm 0.843$ \\
Stearic acid 18:0 & $2.05 \pm 0.581$ \\
Oleic acid $(n-9) 18: 1$ & $9.86 \pm 0.214$ \\
Linoleic acid $(n-6) 18: 2$ & $20.39 \pm 0.672$ \\
Linolenic acid $(n-3) 18: 3$ & $62.21 \pm 0.810$ \\
\hline
\end{tabular}

The chemical composition of ice cream enriched with MDB is presented in Table 3. The obtained ice cream had a high dry matter content, ranging from $40.56 \mathrm{~g}(100 \mathrm{~g})^{-1}$ to $41.02 \mathrm{~g}(100 \mathrm{~g})^{-1}$. Increasing the dry matter content in the ice cream mixture reduces the diameter of the ice crystals, which is very desirable and improves the consistency of the ice cream. In addition, the dry matter content affects the degree of aeration in ice cream [34]. In general, formulations with a high dry matter content produce a better quality ice cream. According to Clarke [1], typical ice cream should contain between $28 \%$ and $40 \%$ dry matter with a fat content between 7 and 15\%. However, according to Goff and Hartel [35], low fat ice cream should contain dry matter in the range of $28-32 \%$ with a milk fat content of $2-5 \%$ and in the case of light ice cream, dry matter is in the range of 30-35\% with a fat content of min. 5-7\%. 
Table 3. Chemical composition of ice cream with the addition of MDB.

\begin{tabular}{cccccc}
\hline Properties & LW1.0 & LW1.5 & LW2.0 & LW2.5 & LW3.0 \\
\hline${\text { Dry matter }\left[\mathrm{g}(100 \mathrm{~g})^{-1}\right]}^{\text {Fat }\left[\mathrm{g}(100 \mathrm{~g})^{-1}\right]^{-1}}$ & $40.56 \pm 0.031^{\mathrm{a}}$ & $40.56 \pm 0.520^{\mathrm{a}}$ & $40.76 \pm 0.331^{\mathrm{a}}$ & $41.25 \pm 0.570^{\mathrm{a}}$ & $41.02 \pm 0.180^{\mathrm{a}}$ \\
Protein $\left[\mathrm{g}(100 \mathrm{~g})^{-1}\right]$ & $10.16 \pm 0.020^{\mathrm{a}}$ & $2.20 \pm 0.013^{\mathrm{a}}$ & $4.08 \pm 0.021^{\mathrm{b}}$ & $4.58 \pm 0.021^{\mathrm{c}}$ & $5.33 \pm 0.010^{\mathrm{d}}$ \\
Ash $\left[\mathrm{g}(100 \mathrm{~g})^{-1}\right]^{\mathrm{b}}$ & $10.66 \pm 0.321^{\mathrm{c}}$ & $11.40 \pm 0.042^{\mathrm{a}}$ & $11.66 \pm 0.032^{\mathrm{a}}$ & $12.07 \pm 0.021^{\mathrm{d}}$ \\
$\mathrm{pH}^{\mathrm{ab}}$ & $5.88 \pm 0.124^{\mathrm{ab}}$ & $1.73 \pm 0.024^{\mathrm{c}}$ & $1.95 \pm 0.044^{\mathrm{ab}}$ & $1.85 \pm 0.022^{\mathrm{ac}}$ & $2.06 \pm 0.021^{\mathrm{b}}$ \\
\hline
\end{tabular}

abcd Means in the same line indicated by different letters were significantly different $(p$ value $<0.05)$. The results are expressed as mean $\pm \operatorname{SD}(n=3)$.

The protein content in the ice cream supplemented with MDB changed significantly $(p<0.05)$ from $10.16 \mathrm{~g}(100 \mathrm{~g})^{-1}$ for the LW1.0 sample to $12.07 \mathrm{~g}(100 \mathrm{~g})^{-1}$ for ice cream with $3.0 \%$ MDB addition. The importance of protein in ice cream is justified by the ability of this compound to stabilize the emulsions after the homogenization process. Proteins also have a large influence on the water-holding capacity of products, improving the viscosity of the mixtures, reducing ice formation, and increasing the melting resistance of ice creams [1]. According to Clarke [1], standard ice cream generally has a protein content of around $4-5 \%$, lower than the values obtained in the present study.

The fat content of ice cream samples is given in Table 3 . All results differed significantly $(p<0.05)$ from each other. That with the increase in the percentage of MDB in the ice cream, the content of fat and fatty acids increases significantly (Table 4). These values for fat ranged from $2.19 \mathrm{~g}(100 \mathrm{~g})^{-1}$ (LW1.0) to $5.33 \mathrm{~g}(100 \mathrm{~g})^{-1}$ (LW3.0). The fat content affects the degree of aeration in the ice cream. Many authors define fat content limits in cream ice cream at the level of 8 and $12 \%$, at which the best air entrainment effect is obtained [1,35]. The ratio of fat content to dry matter content is also important and depends on the type of ice cream. For ice cream made with sucrose, the fat content is three times less than the dry matter content with $70 \%$ aeration, and for ice cream with inulin the fat content is almost five times less than the dry matter content with $43 \%$ aeration [36].

Table 4. Fatty acid content of ice cream with the addition of MDB.

\begin{tabular}{cccccc}
\hline Properties & LW1.0 & LW1.5 & LW2.0 & LW2.5 & LW3.0 \\
\hline Palmitic acid [\%] & $0.05 \pm 0.001^{\mathrm{a}}$ & $0.08 \pm 0.010^{\mathrm{b}}$ & $0.11 \pm 0.010^{\mathrm{c}}$ & $0.14 \pm 0.010^{\mathrm{d}}$ & $0.16 \pm 0.010^{\mathrm{e}}$ \\
Stearic acid [\%] & $0.02 \pm 0.010^{\mathrm{a}}$ & $0.03 \pm 0.013^{\mathrm{ab}}$ & $0.04 \pm 0.014^{\mathrm{ab}}$ & $0.05 \pm 0.013^{\mathrm{ab}}$ & $0.06 \pm 0.021^{\mathrm{b}}$ \\
Oleic acid [\%] & $0.10 \pm 0.001^{\mathrm{a}}$ & $0.15 \pm 0.000^{\mathrm{b}}$ & $0.20 \pm 0.001^{\mathrm{c}}$ & $0.24 \pm 0.011^{\mathrm{d}}$ & $0.30 \pm 0.011^{\mathrm{e}}$ \\
Linoleic acid [\%] & $0.21 \pm 0.011^{\mathrm{a}}$ & $0.31 \pm 0.011^{\mathrm{b}}$ & $0.41 \pm 0.010^{\mathrm{c}}$ & $0.51 \pm 0.022^{\mathrm{d}}$ & $0.61 \pm 0.020^{\mathrm{e}}$ \\
Linolenic acid [\%] & $0.62 \pm 0.01^{\mathrm{a}}$ & $0.93 \pm 0.01^{\mathrm{b}}$ & $1.24 \pm 0.02^{\mathrm{c}}$ & $1.56 \pm 0.08^{\mathrm{d}}$ & $1.87 \pm 0.02^{\mathrm{e}}$ \\
\hline
\end{tabular}

abcde Means in the same line indicated by different letters were significantly different $(p$ value $<0.05)$. The results are expressed as mean $\pm \mathrm{SD}(n=3)$.

As verified in Table 3, the ash content for all the ice cream formulations were similar; however, ice cream sample LW3.0 contained higher amounts $\left(2.06 \mathrm{~g}(100 \mathrm{~g})^{-1}(p<0.05)\right.$.

The effect of addition of MDB on the $\mathrm{pH}$ ice cream presented in Table 3. $\mathrm{pH}$ value ranged between 5.80 and 5.88 and it was observed that the increasing proportion of MDB did not cause significant changes in the $\mathrm{pH}$ of the ice cream. The obtained $\mathrm{pH}$ values were lower than those obtained by other authors of the studies, 6.27-6.52 [37], 6.17-6.48 [38], and 6.65-7.05 [39].

Supplementation of ice cream with MDB also influenced the physical properties of ice cream. The selected features are presented in Table 5. The study of the time of the first drop appearance and the total melting time showed statistically significant differences $(p<0.05)$ for the examined ice cream. The ice cream with a 3\% share of MDB had the highest melting time (the total melting time was $38 \mathrm{~min}$ ). The obtained values of 34.74-38.00 min indicate the high melting resistance of ice cream [40]. Melting characteristics are an important parameter in assessing the quality of ice cream, the correct selection of technology and freezing parameters. The melting point is determined by a number of parameters, such as 
the dry matter content, the size of ice crystals, the number and size of fat particles, as well as the composition of the ice cream mixture [41].

Table 5. Physical properties of the tested samples.

\begin{tabular}{cccccc}
\hline Properties & LW1.0 & LW1.5 & LW2.0 & LW2.5 $^{\text {LW3.0 }}$ \\
\hline First drop [min] & $8.65 \pm 0.812^{\mathrm{c}}$ & $11.19 \pm 1.021^{\mathrm{a}}$ & $11.53 \pm 0.491^{\mathrm{a}}$ & $12.20 \pm 0.954^{\mathrm{ab}}$ & $13.94 \pm 0.961^{\mathrm{b}}$ \\
Complete melting & $34.74 \pm 0.672^{\mathrm{a}}$ & $35.56 \pm 0.391^{\mathrm{a}}$ & $35.83 \pm 0.474^{\mathrm{ab}}$ & $37.35 \pm 0.744^{\mathrm{bc}}$ & $38.00 \pm 0.620^{\mathrm{c}}$ \\
time [min] & $9.25 \pm 0.173^{\mathrm{b}}$ & $11.60 \pm 1.232^{\mathrm{c}}$ & $15.77 \pm 0.901^{\mathrm{a}}$ & $15.74 \pm 0.463^{\mathrm{a}}$ & $28.76 \pm 0.681^{\mathrm{d}}$ \\
Hardness [N] $_{\text {Adhesiveness }}$ & $-15.72 \pm 0.732^{\mathrm{e}}$ & $-21.63 \pm 0.773^{\mathrm{d}}$ & $-27.46 \pm 0.502^{\mathrm{c}}$ & $-32.89 \pm 1.221^{\mathrm{b}}$ & $-44.47 \pm 1.420^{\mathrm{a}}$ \\
\hline $\mathrm{N} \cdot \mathrm{s}]$ & & & & \\
\hline
\end{tabular}

abcde Means in the same line indicated by different letters were significantly different $(p$ value $<0.05)$. The results are expressed as mean $\pm \operatorname{SD}(n=3)$.

The hardness of the tested ice cream differed statistically significantly $(p<0.05)$ and ranged from $9.25 \mathrm{~N}$ to $28.76 \mathrm{~N}$. The highest hardness was recorded for ice cream with a 3.0\% share of MDB (LW3.0) (Table 5). Increasing the percentage of this additive in ice cream resulted in an increase in their hardness. Similar relationships were observed for the adhesiveness (stickiness). Adhesiveness is defined as the work necessary to overcome the attractive forces between the surface of the food product and the surface of other materials with which it comes in contact. Ice cream with a 1.0\% share of MDB (LW1.0) had the lowest adhesiveness $(-15.72 \mathrm{~N} \cdot \mathrm{s})$, while that with a $3.0 \%$ share the highest $(-44.47 \mathrm{~N} \cdot \mathrm{s})$. Numerous factors such as the ingredients used [42,43], fat network, ice phase volume, ice crystal content and ice crystal size [41] influence hardness. The effect of fat content and gum concentration on the adhesiveness of sample was found parallel to the results of the hardness; that may be due to change in ice phase volume, viscosity and texture [43]. The similar trend for these parameters was reported by other researchers $[44,45]$.

Apparent viscosity is a physical property of ice cream. According to Goff and Hartel [35] viscosity is especially important for industry design but there is not a clear optimum value for viscosity. Figure 2 shows the viscosity values for the five tested ice cream samples at variable speed. The study on the viscosity of ice cream with the addition of MDB showed non-linear characteristics, i.e., samples exhibited pseudoplastic behavior. The LW3.0 and LW2.5 samples showed the greatest decrease in viscosity for low speed gradients, while the LW1.0 and LW1.5 samples showed a very low initial viscosity value of 3.2 and $6.6 \mathrm{~Pa} \cdot \mathrm{s}$, respectively. The increase in viscosity along with the increase in the proportion of MDB in ice cream may be caused by the presence of fiber. El Nagar et al. [46] noted that the increase in viscosity in low-fat ice cream with the addition of inulin may cause interactions between the dietary fiber and water as a component of the ice cream mixture.

Table 6 shows the values of the cryoscopic temperature and thermophysical properties (thermal conductivity- $\lambda$, heat capacity $-C$, thermal diffusivity-a) of ice cream with different percentages of bagasse from $D$. moldavica L. seeds. The cryoscopic temperature of the tested samples did not differ statistically significantly and ranged from $-3.5{ }^{\circ} \mathrm{C}$ to $-4.0^{\circ} \mathrm{C}$. This parameter is one of the most important thermophysical properties of food. It is necessary to determine its value when designing and optimizing refrigeration technologies [47-49].

The ice cream containing 2.5\% (LW2.5) of MDB had a lower conductivity coefficient $\left(1.06 \mathrm{~W} \cdot(\mathrm{m} \cdot \mathrm{K})^{-1}\right)$ than ice cream with the share of $1.0 \%(\mathrm{LW} 1.0)$. The highest value of heat capacity $\left(\mathrm{C}=2.72 \mathrm{MJ} \cdot\left(\mathrm{m}^{3} \cdot \mathrm{K}\right)^{-1}\right)$ was recorded for the sample with $1 \%$ addition of MDB (LW1.0). Agrawal et al. [50] reported that thermal conductivity of ice cream ranged from $1.039 \mathrm{~W} \cdot(\mathrm{m} \cdot \mathrm{K})^{-1}$ to $1.071 \mathrm{~W} \cdot(\mathrm{m} \cdot \mathrm{K})^{-1}$ and heat capacity values from $2.516 \mathrm{MJ} \cdot\left(\mathrm{m}^{3} \cdot \mathrm{K}\right)^{-1}$ to $2.542 \mathrm{MJ} \cdot\left(\mathrm{m}^{3} \cdot \mathrm{K}\right)^{-1}$. Thermal diffusivity for ice cream containing 3.0\% (LW3. 0) MDB was significantly higher than the other tested samples and amounted to $0.50 \mathrm{~mm} \mathrm{~m}^{2} \cdot \mathrm{s}^{-1}$. The main factor influencing the thermophysical properties is the amount of frozen water, which also depends on the final temperature of the product. 


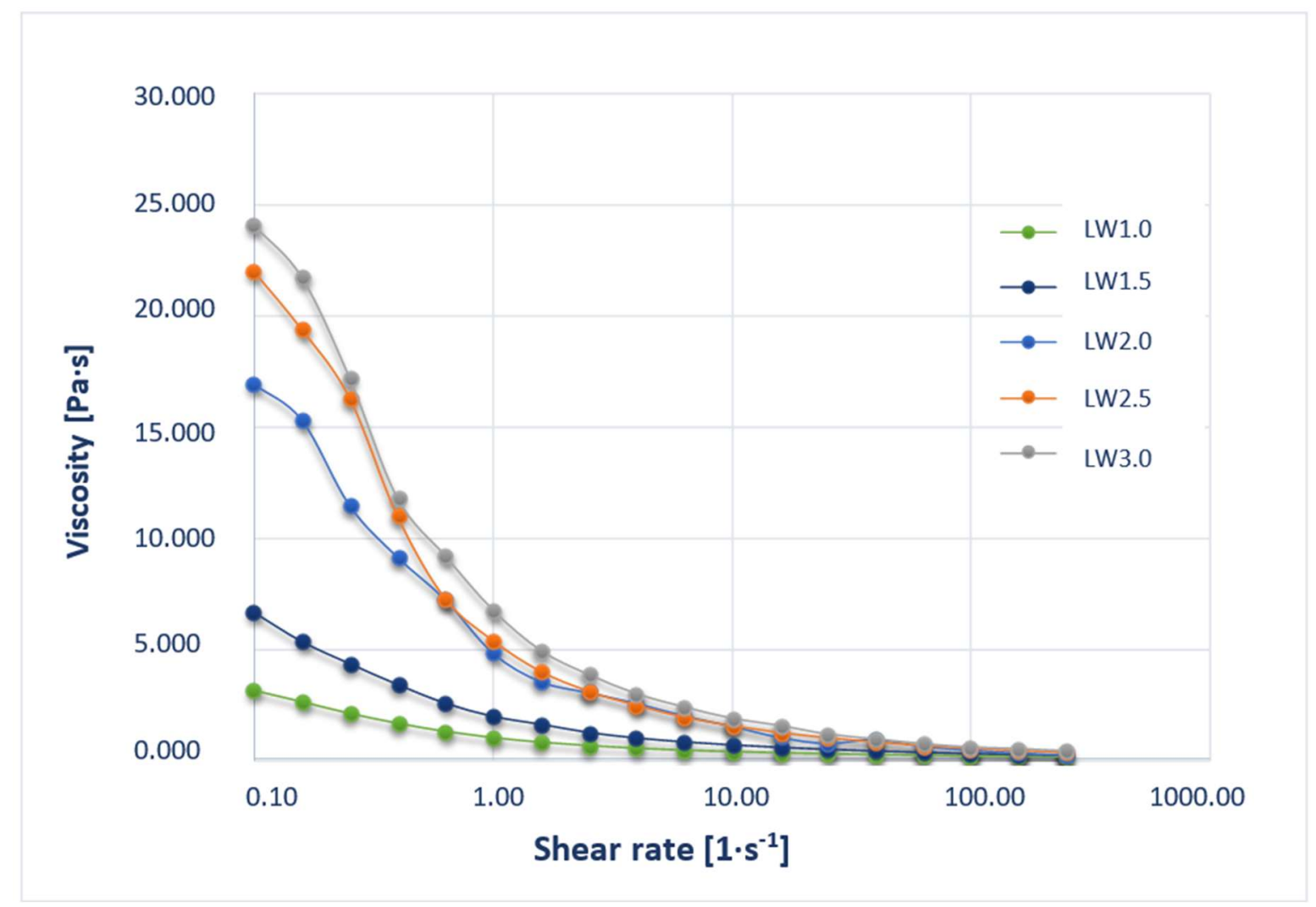

Figure 2. The influence of shear rate on the change in the viscosity of ice cream with $M D B$.

Table 6. Thermophysical properties of the tested ice cream.

\begin{tabular}{|c|c|c|c|c|c|}
\hline Properties & LW1.0 & LW1.5 & LW2.0 & LW2.5 & LW3.0 \\
\hline $\begin{array}{c}\text { Cryoscopic temperature } T_{c r} \\
{\left[{ }^{\circ} \mathrm{C}\right]}\end{array}$ & $-3.50 \pm 0.000^{\mathrm{a}}$ & $-3.50 \pm 0.000^{\mathrm{a}}$ & $-3.50 \pm 0.000^{\mathrm{a}}$ & $-4.00 \pm 0.000^{b}$ & $-4.00 \pm 0.000^{b}$ \\
\hline $\begin{array}{c}\text { Thermal conductivity } \lambda \\
{\left[\mathrm{W} \cdot(\mathrm{m} \cdot \mathrm{K})^{-1}\right]}\end{array}$ & $1.10 \pm 0.021^{\mathrm{c}}$ & $1.08 \pm 0.014^{\mathrm{abc}}$ & $1.09 \pm 0.013^{b c}$ & $1.06 \pm 0.011^{\mathrm{a}}$ & $1.07 \pm 0.014^{\mathrm{ab}}$ \\
\hline $\begin{array}{l}\text { Heat capacity C } \\
{\left[\mathrm{MJ} \cdot\left(\mathrm{m}^{3} \cdot \mathrm{K}\right)^{-1}\right]}\end{array}$ & $2.72 \pm 0.101^{\mathrm{d}}$ & $2.57 \pm 0.042^{\mathrm{a}}$ & $2.55 \pm 0.051^{\mathrm{a}}$ & $2.40 \pm 0.081^{\mathrm{c}}$ & $2.17 \pm 0.032^{b}$ \\
\hline $\begin{array}{l}\text { Thermal diffusivity } a \\
{\left[\mathrm{~mm}^{2} \cdot \mathrm{s}^{-1}\right]}\end{array}$ & $0.40 \pm 0.012^{a}$ & $0.41 \pm 0.051^{\mathrm{a}}$ & $0.42 \pm 0.001^{\mathrm{a}}$ & $0.44 \pm 0.010^{\mathrm{a}}$ & $0.50 \pm 0.001^{b}$ \\
\hline
\end{tabular}

abcd Means in the same line indicated by different letters were significantly different $(p$ value $<0.05)$. The results are expressed as mean $\pm \operatorname{SD}(n=3)$.

\section{Conclusions}

The analysis of ice cream showed a high proportion of linolenic acid (n-3) in the tested samples, especially with 3.0\% share of MDB. Supplementation with MDB increased the content of dry matter, fat, and protein in ice cream. The growing share of MDB affected the physical properties of ice cream, increasing adhesiveness and viscosity, and reducing their melting rate. The increasing share of MDB in ice cream resulted in an unfavorable increase in its hardness. At the same time, it did not have a significant influence on the thermophysical properties of ice cream. However, taking into account the general evaluation of the ice cream, it was found that the increasing share of MDB in the ice cream deteriorated its color and gave it a bitter aftertaste. Hence, the 1\% share of MDB was the most acceptable. However, taking into account the nutritional value of MDB (if the recipe is properly developed), it is possible to obtain rice milk ice cream with potential health-promoting properties, which may have a beneficial effect on the consumer's health. 
Author Contributions: Conceptualization K.K. and S.N.; methodology K.K., S.N., M.N., S.P., M.S.; software A.B.; validation K.K., R.R., N.K.; formal analysis S.P., M.S., M.N.; investigation K.K., S.P.; resources K.K., S.P.; data curation K.K., S.N., N.K.; writing-original draft preparation K.K., S.N.; writing-review and editing K.K., R.R.; visualization K.K., R.R.; supervision, R.R.; project administration K.K., S.P.; funding acquisition K.K., S.P., S.N. All authors have read and agreed to the published version of the manuscript.

Funding: The research was financed by the "Excellent science" program of the Ministry of Education and Science as a part of the contract no. DNK/SP/465641/2020. The role of the agricultural engineering and environmental engineering in the sustainable agriculture development.

Institutional Review Board Statement: Not applicable.

Informed Consent Statement: Informed consent was obtained from all subjects involved in the study.

Data Availability Statement: Correspondence and requests for materials should be addressed to R.R.

Conflicts of Interest: The authors declare no potential conflict of interest concerning the research, authorship, and/or publication of this article.

\section{References}

1. Clarke, C. The Science of Ice Cream; Unilever R\&D Colworth/The Royal Society of Chemistry: Cambridge, UK, 2012.

2. Wójtowicz, A.; Oniszczuk, A.; Oniszczuk, T.; Kocira, S.; Wojtunik, K.; Mitrus, M.; Kocira, A.; Widelski, J.; Skalicka-Woźniak, K. Application of Moldavian dragonhead (Dracocephalum moldavica L.) leaves addition as a functional component of nutritionally valuable corn snacks. J. Food Sci. Technol. 2017, 54, 3218-3229. [CrossRef]

3. Oniszczuk, T.; Kasprzak-Drozd, K.; Olech, M.; Wójtowicz, A.; Nowak, R.; Rusinek, R.; Szponar, J.; Combrzyński, M.; Oniszczuk, A. The impact of formulation on the content of phenolic compounds in snacks enriched with Dracocephalum moldavica L. seeds: Introduction to receiving a new functional food product. Molecules 2021, 26, 1245. [CrossRef]

4. Mafakheri, S.; Omidbaigi, R.; Sefidkon, F.; Rejali, F. Effect of biofertilizers, vermicompost, Azotobacter and biophosphate on the growth, nutrient uptake and essential oil content of dragonhead (Dracocephalum moldavica L.). Acta Hortic. 2013, 27, 596-605. [CrossRef]

5. Abd El-Baky, H.H.; El-Baroty, G.S. Chemical and biological evaluation of the essential oil of Egyptian moldavian balm (Dracocephalum moldavica L). Int. J. Integr. Biol. 2008, 3, 202-213. Available online: http://ijib.classicrus.com/trns/2953501629222517.pdf (accessed on 13 August 2021).

6. Dastmalchi, K.; Dorman, D.H.J.; Laakso, I.; Hiltunen, R. Chemical composition and antioxidative activity of Moldavian balm (Dracocephalum moldavica L.) extracts. LWT_Food Sci. Technol. 2007, 40, 239-248. [CrossRef]

7. Matwijczuk, A.; Oniszczuk, T.; Matwijczuk, A.; Chruściel, E.; Kocira, A.; Niemczynowicz, A.; Wójtowicz, A.; Combrzyński, M.; Wiacek, D. Use of FTIR spectroscopy and chemometrics with respect to storage conditions of Moldavian Dragonhead Oil. Sustainability 2019, 11, 6414. [CrossRef]

8. Oniszczuk, T.; Matwijczuk, A.; Matwijczuk, A.; Kocira, S.; Niemczynowicz, A.; Combrzyński, M.; Wójtowicz, A.; Kuboń, M.; Kusz, A.; Oniszczuk, A. Impact of storage temperature and time on Moldavian dragonhead oil-Spectroscopic and chemometric analysis. Open Chem. 2019, 17, 609-620. [CrossRef]

9. Domokos, J.; Peredi, J.; Halasz-Zelnik, K. Characterization of seed oils of dragonhead (Dracocephalum moldavica L.) and catnip (Nepeta cataria var. citriodora Balb.). Ind. Crops Prod. 1994, 3, 91-94. [CrossRef]

10. Dziki, D.; Miś, A.; Gładyszewska, B.; Laskowski, J.; Kwiatkowski, S.; Gawlik-Dziki, U. Physicochemical and grinding characteristics of dragonhead seeds. Int. Agrophysics 2013, 27, 403-408. [CrossRef]

11. Zeng, Q.; Jin, H.Z.; Fu, J.J.; Qin, J.J.; Hu, X.J.; Liu, J.H.; Yan, L.; Chen, M.; Zhang, W.D. Chemical constituents of plants from the genus Dracocephalum. Chem. Biodivers. 2010, 7, 1911-1929. [CrossRef]

12. Yang, S.; Wang, L.; Guo, X.; Lou, H.; Ren, D. A new flavonoid glycoside and other constituents from Dracocephalum moldavica. Nat. Prod. Res. 2013, 27, 201-207. [CrossRef]

13. Jiang, J.; Yuan, X.; Wang, T.; Chen, H.; Zhao, H.; Yan, X.; Wang, Z.; Sun, X.; Zheng, Q. Antioxidative and cardioprotective effects of total flavonoids extracted from dracocephalum moldavica L. against acute ischemia/reperfusion-induced myocardial injury in isolated rat heart. Cardiovasc. Toxicol. 2014, 14, 74-82. [CrossRef]

14. Povilaityté, V.; Cuvelier, M.E.; Berset, C. Antioxidant properties of moldavian dragonhead (Dracocephalum moldavica L.). J. Food Lipids 2001, 8, 45-64. [CrossRef]

15. Dastmalchi, K.; Dorman, D.H.J.; Koşar, M.; Hiltunen, R. Chemical composition and in vitro antioxidant evaluation of a watersoluble Moldavian balm (Dracocephalum moldavica L.) extract. LWT_Food Sci. Technol. 2007, 40, 1655-1663. [CrossRef]

16. El-Baky, H.H.A.; El-Baroty, G.S. Chemical and biological evaluation of the essential oil of Egyptian Moldavian balm. Int. J. Essent. Oil Ther. 2008, 2, 78-81.

17. Sonboli, A.; Mojarrad, M.; Gholipour, A.; Ebrahimi, S.N.; Arman, M. Biological activity and composition of the essential oil of Dracocephalum moldavica L. grown in Iran. Nat. Prod. Commun. 2008, 3, 1547-1550. [CrossRef] 
18. Fattahi, A.; Shakeri, A.; Tayarani-Najaran, Z.; Kharbach, M.; Segers, K.; Heyden, Y.V.; Taghizadeh, S.F.; Rahmani, H.; Asili, J. UPLCPDA-ESI-QTOF-MS/MS and GC-MS analysis of Iranian Dracocephalum moldavica L. Food Sci. Nutr. 2021. [CrossRef] [PubMed]

19. Kakasy, A.Z.; Lemberkovics, É.; Simándi, B.; Lelik, L.; Héthelyi, É.; Antal, I.; Szöke, É. Comparative study of traditional essential oil and supercritical fluid extracts of Moldavian dragonhead (Dracocephalum moldavica L.). Flavour Fragr. J. 2006, 21, 598-603. [CrossRef]

20. Frąc, M.; Oszust, K.; Kocira, A.; Kocira, S. Molecular Identification of Fungi Isolated from Dracocephalum Moldavica, L. Seeds. Agric. Agric. Sci. Proced. 2015, 7, 74-79. [CrossRef]

21. Dziki, D.; Cacak-Pietrzak, G.; Gawlik-Dziki, U.; Sułek, A.; Kocira, S.; Biernacka, B. Effect of Moldavian dragonhead (Dracocephalum moldavica L.) leaves on the baking properties of wheat flour and quality of bread. CYTA—J. Food 2019, 17, 536-543. [CrossRef]

22. Oniszczuk, T.; Wójtowicz, A.; Combrzyński, M.; Mitrus, M.; Kupryaniuk, K.; Matysiak, A.; Kocira, S.; Oniszczuk, A. Selected properties of snacks extruded at various screw speeds supplemented with Moldavian dragonhead seed addition. Int. Agrophysics 2019, 33, 363-371. [CrossRef]

23. Zarzycki, P.; Teterycz, D.; Wirkijowska, A.; Kozłowicz, K.; Stasiak, D.M. Use of moldavian dragonhead seeds residue for pasta production. LWT-Food Sci. Technol. 2021, 143, 111099. [CrossRef]

24. Oniszczuk, T.; Wójtowicz, A.; Kocira, S.; Żelizko, K.; Oniszczuk, A.; Dib, A. The Use of Moldavian Dragonhead Bagasse Waste in Extruded Products. In Proceedings of the IX International Scientific Symposium Farm Machinery and Processes Management in Sustainable Agriculture, Lublin, Poland, 22-24 November 2017. [CrossRef]

25. ISO Standard 12966-2:2017. Animal and Vegetable Fats and Oils Gas Chromatography of Fatty acid Methyl esters-Part 2: Preparation of Methyl Esters of Fatty Acids; ISO International Organization for Standardization: Geneva, Switzerland, 2017.

26. AOAC International. Official Methods of Analysis of AOAC International, 17th ed.; Association of Analytical Communities: Gaithersburg, MD, USA, 2000.

27. Rahman, M.S.; Guizani, N.; Al-Khaseibi, M.; Al-Hinai, S.A.; Al-Maskri, S.S.; Al-Ramhami, K. Analysis of cooling curve to determine the end point of freezing. Food Hydrocol. 2002, 16, 653-659. [CrossRef]

28. Güven, M.; Karaca, O.B. The effect of varying sugar content and fruit concentration on the physical properties of vanilla and fruit ice-cream-type frozen yogurts. Int. J. Dairy Technol. 2002, 55, 27-31. [CrossRef]

29. Tiwari, A.; Sharma, H.K.; Kumar, N.; Kaur, M. The effect of inulin as a fat replacer on the quality of low-fat ice cream. Int. J. Dairy Technol. 2015, 68, 374-380. [CrossRef]

30. Kozłowicz, K.; Góral, D.; Kluza, F.; Góral, M.; Andrejko, D. Experimental determination of thermophysical properties by line heat pulse method. J. Food Meas. Charact. 2018, 12, 2524-2534. [CrossRef]

31. Abdel-Reheem, M.A.; Bhella, R.; Hilderbrand, D. Linolenic acid accumulation in Dracocephalum moldavica L. Lipids 2008, 43, 749-755.

32. Stuchlik, M.; Žak, S. Vegetable lipids as component of functional foods. Biomed. Pap. 2002, 146, 3-10. [CrossRef]

33. Hanczakowski, P.; Szymczyk, B.; Kwiatkowski, S.; Wolski, T. Composition and nutritive value of protein of Moldavian balm seeds (Dracocephalum moldavica L.). Rocz. Nauk Zoot. 2009, 36, 55-61.

34. Kamińska-Dwórznicka, A.; Janczewska-Dupczyk, A.; Kot, A.; Łaba, S.; Samborska, K. The impact of ı- and k-carrageenan addition on freezing process and ice crystals structure of strawberry sorbet frozen by various methods. J. Food Sci. 2020, 85, 50-56. [CrossRef]

35. Goff, H.D.; Hartel, R.W. Ice Cream; Springer Science: New York, NY, USA, 2013.

36. Ostróżka, K.; Wichrowska, D. Effect of sugar substitutes on aeration degree and meltability of medium-hard dairy ice cream. Żywność. Nauka. Technol. Jakość. 2020, 27, 52-65. [CrossRef]

37. Karaca, O.B.; Güven, M.; Yasar, K.; Kaya, S.; Kahyaoglu, T. The functional, rheological and sensory characteristics of ice creams with various fat replacers. Int. J. Dairy Technol. 2009, 62, 93-99. [CrossRef]

38. Dervisoglu, M. Influence of hazelnut flour and skin addition on the physical, chemical and sensory properties of vanilia ice cream. Int. J. Food Sci. Technol. 2006, 41, 657-661. [CrossRef]

39. Qayyum, A.; Huma, N.; Sameen, A.; Siddiq, A.; Munir, M. Impact of watermelon seed flour on the physico-chemical and sensory characteristics of ice cream. J. Food Process. Preserv. 2017, 41, e13297. [CrossRef]

40. Muse, M.R.; Hartel, R.W. Ice cream structural elements that affect melting rate and hardness. J. Dairy Sci. 2004, 87, 1-10. [CrossRef]

41. Rahim, N.A.; Sarbon, N.M. Acacia honey lime ice cream: Physicochemical and sensory characterization as effected by different hydrocolloids. Int. Food Res. J. 2019, 26, 883-891. Available online: http:/ / www.ifrj.upm.edu.my/26\%20\%202019/18\%20-\%20 IFRJ17773.R1-Final.pdf (accessed on 13 August 2021).

42. Su-Jung, Y.; Ji-Han, K.; Go-Eun, H.; Woojoon, P.; Soo-Ki, K.; Han-Geuk, S.; Chi-Ho, L. Physical and sensory properties of ice cream containing fermented pepper power. Korean J. Food Sci. An. 2017, 37, 38-43.

43. Javidi, F.; Razavi, S.M.A. Rheological, physical and sensory characteristocs of light ice cream as affected by selected fat replacers. J. Food Measur. Charact. 2018, 12, 1872-1884. [CrossRef]

44. Akalin, A.S.; Karagözlü, C.; Ünal, G. Rheological Properties of Reduced-Fat and Low-Fat Ice Cream Containing Whey Protein Isolate and Inulin. Eur. Food Res. Technol. 2008, 227, 889-895. [CrossRef]

45. Aime, S.D.; Arntfield, L.; Malcolmson, L.; Ryland, D. Textural analysis of fat reduced vanilla ice cream products. Food Res. Int. 2001, 34, 237-246. [CrossRef] 
46. El-Nagar, G.; Clowes, G.; Tudorica, C.M.; Kuri, V.; Brennan, C.S. Rheological quality and stability of yog-ice cream with added inulin. Int. J. Dairy Technol. 2002, 55, 89-93. [CrossRef]

47. Tello, H.A.; Peralta, J.M.; Rubiolo, A.C.; Zorrilla, S.E. Prediction of the freezing point of multicomponent liquid refrigerant solutions. J. Food Eng. 2011, 104, 143-148. [CrossRef]

48. Kozłowicz, K.; Góral-Kowalczyk, M.; Góral, D.; Pankiewicz, U.; Bronowicka-Mielniczuk, U. Effect of ice cream storage on the physicochemical properties and survival of probiotic bacteria supplemented with zinc ions. LWT-Food Sci. Technol. 2019, 116, 108562. [CrossRef]

49. Góral, M.; Kozłowicz, K.; Pankiewicz, U.; Góral, D. Magnesium enriched lactic acid bacteria as a carrier for probiotic ice cream production. Food Chem. 2018, 15, 1151-1159. [CrossRef] [PubMed]

50. Agrawal, A.K.; Karkhele, P.D.; Sandey, K.K.; Sahu, C.; Sinha, G. Effect of incorporation of ginger juice in various rates on the freezing and thermal properties of ice cream. Asian J. Dairy Food Res. 2015, 34, 92-97. [CrossRef] 